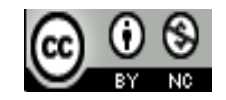

Jurnal Pendidikan Matematika Indonesia is licensed under A Creative Commons Attribution-Non Commercial 4.0 International License

\title{
Analisis Kelancaran Prosedural Matematis SisWa Pada Materi PERSAMAAN EKSPONEN KELAS X SMA NEgERI 2 SingKaWANG
}

\author{
Uray Windi Haryandika ${ }^{1)}$ Citra Utami ${ }^{2)}$ Nindy Citroresmi Prihatiningtyas ${ }^{3)}$ \\ 1) Prodi Pendidikan Matematika STKIP Singkawang, Indonesia \\ E-mail: uraywindi14@gmail.com \\ 2) Prodi Pendidikan Matematika STKIP Singkawang, Indonesia \\ E-mail: citrautami1990@gmail.com \\ 3) Prodi Pendidikan Matematika STKIP Singkawang, Indonesia \\ E-mail: nindy.citroresmi@yahoo.com
}

\begin{abstract}
Abstrak. Penelitian ini bertujuan untuk mendeskripsikan kelancaran prosedural matematis siswa. Penelitian ini dilaksanakan di SMA Negeri 2 Singkawang. Jenis penelitian yang digunakan adalah kualitatif, bentuk penelitian yang digunakan deskriptif. Subjek penelitian adalah siswa kelas Xa SMA Negeri 2 Singkawang. Pengambilan data menggunakan instrumen berupa tes essay yang disesuaikan dengan karekteristik kelancaran prosedural matematis dan telah diujikan dengan validasi isi, validasi konstruk, reliabilitas, tingkat kesukaran dan daya pembeda. Hasil penelitian menunjunkan kelancaran prosedural matematis siswa; (1) kelompok atas yaitu $64 \%$ dengan kategori rendah, khususnya pada indikator fleksibel yaitu $74 \%$ dengan kategori sedang, indikator efisien yaitu $78 \%$ dengan kategori sedang dan indikator efektif yaitu 41\% dengan kategori sangat rendah; (2) kelompok tengah yaitu 53\% dengan kategori sangat rendah, khususnya pada indikator fleksibel yaitu 90\% dengan ketegori sangat tinggi, indikator efisien yaitu $36 \%$ dengan kategori sangat rendah dan pada indikator efektif yaitu 33\% dengan kategori sangat rendah; (3) kelompok bawah yaitu 34\% dengan kategori sangat rendah, khususnya pada indikator fleksibel yaitu $48 \%$ dengan kategori sangat rendah, indikator efisien yaitu $33 \%$ dengan kategori sangat rendah dan pada indikator efektif yaitu 22\% dengan kategori sangat rendah
\end{abstract}

Kata Kunci: Kelancaran Prosedural Matematis, Persamaan Eksponen

\section{PENDAHULUAN}

Matematika merupakan disiplin ilmu yang mempunyai sifat khas. Kekhasan itu berkenaan dengan ide-ide atau konsep-konsep abstrak yang tersusun secara hirarkis (Rosmaiyadi, 2017). Matematika merupakan ilmu yang mendasari perkembangan teknologi modern, mempunyai peranan penting dalam berbagai disiplin ilmu dan memajukan daya pikir manusia (Sari, Wahyuni, \& Rosmaiyadi, 2016). Matematika adalah ilmu yang membahas angka-angka dalam perhitungannya, membahas masalah-masalah numerik, mengenai kuantitas dan besaran, mempelajari hubungan pola, bentuk dan sarana berpikir, kumpulan sistem, struktur dan alat (Hamzah \& Muhlisrarini, 2014). Untuk sukses dalam belajar matematika siswa memerlukan banyak hal diantaranya adalah guru yang kompeten, kurikulum yang menjanjikan kesempatan kepada siswa untuk mempelajari konsep-konsep dan prosedur-prosedur matematis yang penting dan bermakna, lingkungan atau kelas yang mendukung proses pembelajaran. Faktor yang sangat berperan dalam menunjang kesuksesan belajar matematika siswa adalah kecakapan matematis (mathematical profeciency) (Kilpatrick, Swafford, \& Findell, 2001). Kecakapan matematis siswa terdiri dari lima komponen, satu diantara lima komponen tersebut adalah kelancaran prosedural matematis (Stott, 2013).

Kelancaran prosedural didefinisikan sebagai keterampilan dalam melaksanakan prosedur secara fleksibel, efisien dan efektif (Sullivan, 2011). Kelancaran prosedural mengacu pada pengetahuan tentang prosedur, pengetahuan saat dan bagaimana 
menggunakannya dengan tepat, dan keterampilan dalam melakukan fleksibel, efisien dan efektif dalam menyelesaikan suatu (Kilpatrick, Swafford, \& Findell, 2001). Russel membagi tiga aspek kelancaran prosedural matematis, yaitu fleksibel, efisien dan efektif (Aprianti, 2014). Pertama, fleksibel memerlukan pengetahuan pendekatan yang lebih dari satu untuk menyelesaikan suatu masalah tertentu. Fleksibel yang dimaksud adalah saat siswa menyelesaikan suatu masalah, siswa dapat memilih satu diantara strategi maupun metode yang ada dan sesuai untuk mengecek ulang hasilnya. Kedua, efisien secara tidak langsung menyatakan bahwa siswa tidak terhenti pada langkah-langkah yang banyak dan tidak kehilangan arah dalam strategi berlogika. Ketiga, efektif tergantung pada beberapa aspek dari proses pemecahan masalah, termasuk perekaman yang hati-hati, pengetahuan kombinasi bilangan, dan memperhatikan hasil dari pengecekan yang berulang dengan tepat. Dapat disimpulkan bahwa kelancaran prosedural matematis siswa merupakan keterampilan siswa tentang cara untuk memperkirakan hasil menggunakan langkahlangkah dalam menyelesaikan soal.

Kelancaran prosedural matematis memiliki pengaruh yang penting terhadap kompetensi matematika siswa di sekolah (Kilpatrick, Swafford, \& Findell, 2001). Tanpa kelancaran prosedural matematis yang cukup, siswa sulit dalam memehami pemahaman mereka tentang matematika atau memecahkan masalah matematika dalam pembelajaran. Siswa harus fleksibel,efisien dan efektif dalam melakukan perhitungan, tanpa selalu harus mengacu pada alat bantu. Siswa juga perlu tahu cara yang fleksibel, efisien dan efektif dalam melakukan pengoperasian matematika, misalnya menambah, mengurangi, mengalikan, dan membagi tanpa mengguakan alat bantu seperti kalkulator. Dalam menyelesaikan masalah dalam matematika siswa tidak hanya diminta untuk memberikan hasil akhir yang benar. Tetapi siswa dituntut lebih kreatif menggunakan keterampilan mereka untuk mencari hasil akhir yang benar dan tepat menggunakan prosedur atau langkah-lagkahnya tanpa berpatokan pada alat bantu.
Namun pada kenyataanya siswa SMA Negeri 2 Singkawang diduga belum sepenuhnya memiliki kelancaran prosedural matematis yang baik atau ada kecendrungan bahwa siswa di dalam belajar matematika kurang memiliki kelacaran prosedural matematis. Hal ini teramati selama peneliti melaksanakan tugas Program Pengalaman Lapangan (PPL) di SMA Negeri 2 Singkawang. Seringkali siswa menanyakan langkah-langkah apa yang dilakukan untuk menyelesaikan soal yang mereka kerjakan. Sejalan dengan hal itu, untuk mengetahui kelancaran prosedural matematis siswa peneliti melakukan wawancara kepada beberapa siswa. Hasil wawancara dapat disimpulkan bahwa siswa masih tidak tahu kapan dan bagaimana menggunakan prosedur secara fleksibel, efisien dan efektif, mereka hanya dapat mengerjakan soal yang sama dengan contoh soal yang guru jelaskan dipapan tulis.

Untuk mengetahui lebih jelas kelancaran prosedural matematis siswa, peneliti melakukan wawancara secara tidak terstruktur atau hanya berupa garis besar mengenai prosedur siswa dalam meyelesaikan soal kepada seorang guru matematika di SMA Negeri 2 Singkawang. Dari hasil wawancara secara keseluruhan masih banyak siswa yang mendapat nilai rendah pada ulangan harian yaitu memecahkan masalah yang berkaitan dengan bentuk pangkat dan akar atau hanya beberapa siswa yang dapat mencapai ketuntasan. Pada ulangan harian tersebut banyak siswa yang tidak mampu menjawab soal khususnya pada materi persamaan eksponen, sehingga nilai ulangan siswa pada banyak yang rendah. Siswa juga belum mampu menguasai atau bahkan memahami langkah-langkah dari suatu materi persamaan eksponen. Siswa hanya mengerti apa yang dijelaskan dan dicontohkan oleh guru dan contoh di dalam buku paket LKS dengan tipe soal yang sama. Pada saat guru memberikan latihan tipe soal yang berbeda, siswa mulai menanyakan lagkah-langkah apa yang harus dilakukan untuk menyelesaikan soal tersebut.

Dari data hasil belajar matematika siswa yang didapat peneliti selama melaksanakan tugas PPL, hasil nilai UTS siswa rata-rata hanya mencapai 54 yang tentunya jauh dari Kriteria Ketuntasan Minimal (KKM) yang menjadi ketetapan SMA 
Negeri 2 Singkawang yaitu 65. Dari soal UTS tersebut menuntut siswa untuk lebih kreatif menggunakan prosedur dalam upaya mendapatkan hasil akhir yang benar. Untuk lebih jelas mengenai jawaban satu diantara siswa kelas X SMA Negeri 2 Singkawang dalam menyelesaikan soal UTS.

Permasalahan yang dibahas di atas menunjukan bahwa begitu pentingnya kelancaran prosedural matematis siswa dalam pembelajaran matematika, membuat peneliti tertarik untuk mengungkapkan lebih jauh mengenai kelancaran prosedural matematis siswa. Martinez-pons menyatakan bahwa, upaya pembelajaran sangat penting bagi seorang pendidik untuk melaksanakan fase awal pada pembelajaran (Aprianti, 2014). Fase ini merupakan tahap seorang pendidik untuk mengetahui dan memahami bekal awal yang dimiliki siswanya. Bekal awal yang termasuk dalam tahap tersebut adalah mengetahui kemampuan siswa dalam belajar. Pendapat menurut para ahli ini mendukung untuk dilakukannya penelitian mengenai kelancaran prosedural matematis siswa.

Berdasarkan permasalahan yang telah dibahas pada paragraf sebelumnya, maka peneliti tertarik untuk melakukan penelitian dengan judul "analisis kelancaran prosedural matematis siswa pada materi persamaan eksponen kelas X SMA Negeri 2 Singkawang."

\section{METODE}

Metode pengumpulan data adalah suatu proses pengumpulan data primer dan sekuder dalam suatu penelitian (Siregar, 2014). Metode penelitian ini adalah metode deskriptif dengan pendekatan kualitatif. Subjek penelitian adalah benda, hal, atau orang yang padanya melekat data tentang objek penelitian (Silalahi, 2009). Subjek yang akan diteliti pada penelitian ini adalah siswa kelas Xa SMA Negeri 2 Singkawang berjumlah 31 orang, yang terdiri dari 13 siswa laki-laki dan 18 siswa perempuan. Objek penelitian adalah apa yang menjadi titik perhatian suatu penelitian (Arikunto, 2010). Objek dalam penelitian ini adalah kelancaran prosedural matematis siswa pada materi persamaan eksponen.

Metode pengumpulan data dalam penelitian ini dengan menggunakan metode tes. Metode tes adalah memperoleh data tentang status sesuatu dibandingkan dengan standar atau ukuran yang telah ditentukan, dengan mengadakan pengukuran (Arikunto, 2010). Metode tes ini digunakan untuk mengukur dan mendapatkan data tingkat kelancaran prosedural matematis siswa kelas $\mathrm{X}$ SMA Negeri 2 Singkawang. Data yang dikumpulkan dalam penelitian ini berupa kuantitatif yang kemudian akan dideskripsikan secara kualitatif dalam bentuk kata-kata. Selain itu, peneliti menggunakan metode wawancara. Metode ini digunakan sebagai pelengkap data, untuk menilai atau mengetahui keadaan subjek dalam menyelesaikan tes kelancaran prosedural matematis siswa pada materi persamaan eksponen. Peneliti juga menggunakan metode dokumentasi. Dokumentasi digunakan untuk mendapatkan bukti otentik dan pemahaman tentang kejadian atau peristiwa yang telah dan akan terjadi (Aliyansah, 2013).

Instrumen pengumpulan data dalam penelitian ini adalah tes kelancaran procedural matematis. Tes digunakan untuk mengukur kelancaran prosedural matematis siswa dalam materi persamaan eksponen adalah dengan memberikan tes tertulis bentuk essay berjumlah 3 soal yang mencangkup 3 indikator kelancaran prosedural matematis siswa pada materi pokok persamaan eksponen. Tes essay merupakan tes yang menghendaki testee (peserta tes) memberikan jawaban dalam bentuk uraian atau kalimat-kalimat yang disusun sendiri (Nawawi, 2015). Selain itu, instrument yang digunakan adalah pedoman wawancara. Wawancara digunakan sebagai teknik pengumpulan data apabila peneliti ingin melakukan studi pendahuluan untuk menemukan permasalahan yang harus diteliti (Sugiyono, 2010). Wawancara digunakan hanya untuk memperoleh informasi secara langsung mengenai garis-garis besar permasalahan dalam menyelesaikan soal tes kelancaran prosedural matematis pada materi persamaan eksponen. Instrumen pengumpulan data berupa tes terlebih dulu di uji validitas, reliabilitas, daya pembeda dan tingkat kesukarannya.

Validitas bertujuan agar tes yang digunakan benar-benar untuk mengukur kemampuan siswa dalam menyelesaikan soal persamaan eksponen, 
maka instrumen yang telah disusun diukur dengan validitas tes. Adapun hasil perhitungan validitas dapat dilihat pada Tabel 1. Perhitungan Validitas Uji Coba Soal berikut ini.

TABEL I

Perhitungan Uji CoBA SOAL

\begin{tabular}{cccc}
\hline Soal & Nomor $\mathbf{1}$ & Nomor $\mathbf{2}$ & Nomor 3 \\
\hline Validitas & 0,52 & 0,71 & 0,80 \\
Kriteria & Sedang & Tinggi & Tinggi \\
\hline
\end{tabular}

Reliabilitas menunjukkan pada suatu pegertian bahwa suatu instrumen cukup dapat dipercaya untuk digunakan sebagai alat pengumpulan data karena instrumen tersebut sudah baik. Berdasarkan hasil perhitungan uji coba soal diperoleh bahwa reliabilitas sebesar 0,46 dengan kriteria sedang. Sedangkan daya pembeda adalah kemampuan dari tes tersebut dalam memisahkan antara subjek yang pandai dengan subjek yang kurang pandai. Adapun hasil perhitungan daya pembeda dapat dilihat pada Tabel II sebagai berikut.

TABEL II

Perhitungan Daya PeMBeda Uji CoBa SoAL

\begin{tabular}{cccc}
\hline Soal & Nomor 1 & Nomor 2 & Nomor 3 \\
\hline $\begin{array}{c}\text { Daya } \\
\text { Pembeda } \\
\text { Kriteria }\end{array}$ & 0,26 & 0,53 & 0,48 \\
& Cukup & Baik & Baik \\
\hline
\end{tabular}

Tingkat kesukaran bertujuan untuk mengkaji soal-soal soal tes yang diuji cobakan dari sisi kesulitannya, sehingga dapat diperoleh soal-soal yang termasuk dalam kategori mudah, sedang dan sukar. Adapun hasil perhitungan tingkat kesukaran dapat dilihat pada Tabel III. Perhitungan Tingkat Kesukaran Uji Coba Soal sebagai berikut.

TABEL III

Perhitungan TingKat KesuKaran Uji CoBA SoAL

\begin{tabular}{cccc}
\hline Soal & Nomor 1 & Nomor 2 & Nomor 3 \\
\hline $\begin{array}{c}\text { Tingkat } \\
\text { Kesukaran } \\
\text { Kriteria }\end{array}$ & 0,71 & 0,68 & 0,65 \\
\hline
\end{tabular}

III. HASIL DAN PEMBAHASAN

Berdasarkan hasil analisis data dapat diketahui yaitu tingkat kelancaran prosedural matematis siswa kelas X SMA Negeri 2 Singkawang pada indikator fleksibel tertinggi dengan angka persentase sebesar 90\% dengan kategori sangat tinggi yaitu berada pada kelompok tengah. Sedangkan tingkat kelancaran prosedural matematis terendah dengan angka persentase $48 \%$ yaitu kelompok bawah, dengan kategori sangat rendah. Sedangkan untuk kelompok atas berada pada tingkat kelancaran prosedural matematis yang kedua dengan angka persentase $74 \%$, dengan kategori sedang.

Sedangkan tingkat kelancaran prosedural matematis siswa kelas $\mathrm{X}$ SMA Negeri 2 Singkawang pada indikator efisien tertinggi dengan angka persentase sebesar 78\% dengan kategori sedang, yaitu berada pada kelompok atas. Sedangkan tingkat kelancaran prosedural matematis terendah dengan angka persentase 33\% dengan kategori sangat rendah, yaitu berada pada kelompok bawah. Sedangkan untuk kelompok tengah berada pada tingkat kelancaran prosedural matematis yang kedua dengan angka persentase $36 \%$ dengan kategori sangat rendah.

Tingkat kelancaran prosedural matematis siswa kelas X SMA Negeri 2 Singkawang pada indikator efisien tertinggi dengan angka persentase sebesar $41 \%$ dengan kategori sangat rendah, yaitu berada pada kelompok atas. Sedangkan tingkat kelancaran prosedural matematis terendah dengan angka persentase $32 \%$ dengan kategori sangat rendah, yaitu berada pada kelompok bawah. Sedangkan untuk kelompok tengah berada pada tingkat kelancaran prosedural matematis kedua dengan angka persentase $33 \%$ dengan kategori sangat rendah.

Berdasarkan hasil analisis data, persentase kelacaran prosedural matematis siswa kelompok atas yang berjumlah 9 siswa yaitu 64\% dengan kategori rendah. Sedangkan persentase kelacaran prosedural matematis siswa kelompok tengah yang berjumlah 13 siswa yaitu 53\% dengan kategori sangat rendah dan persentase kelacaran prosedural matematis siswa kelompok bawah yang berjumlah 9 siswa yaitu 34\% dengan kategori sangat rendah. Sehingga dapat disimpulkan kelancaran prosedural matematis siswa kelas $X$ SMA Negeri 2 Singkawang masih tergolong rendah. Rendahnya kelancaran prosedural matematis siswa, diduga saat pembelajaran matematika berlangsung, latihan kelancaran prosedur belum diberikan kepada siswa. Rendahnya kelancaran prosedural matematis siswa merupakan suatu masalah dalam pembalajaran matematika disekolah yang harus 
ditindaki bagi seorang pendidik, hal ini guna untuk memperbaiki prestasi belajar dan hasil belajar matematika siswa disekolah.

Dalam memperbaiki rendahnya kelancaran prosedural matematis siswa, perlunya teori-teori belajar dalam upaya meningkatkan rendahnya kelancran prosedural matematis siswa. Teori belajar yang mendukung kelancaran prosedural diantaranya adalah teori belajar Bruner dan teori belajar Gagne. Teori belajar Bruner memusatkan perhatiannya pada masalah apa yang dilakukan manusia dengan informasi yang diterimanya dan apa yang dilakukannya sesudah memperoleh informasi yang diskret itu mencapai pemahaman yang memberikan kemampuan kepadanya. Bruner mengemukakan empat tema pedidikan yaitu; (1) pentingnya struktur pengetahuan; (2) kesiapan belajar; (3) nilai intuisi dalam proses pendidikan; (4) motivasi untuk (Dahar, 2006).

Sedangkan menurut teori belajar Gagne lima kemampuan yang dikatakan sebagai hasil belajar yaitu; (1) keterampilan intelektual; (2) strategi kognitif; (3) sikap; (4) informasi verbal; (5) keterampilan motorik (Dahar, 2006). Keterampilan intelektual memungkinkan seseorang berinteraksi dengan lingkungannya dengan penggunaan simbol-simbol atau gagasangagasan. Strategi kognitif merupakan keterampilan khusus yang mempunyai kepentingan bagi belajar dan berpikir. Invormasi verbal disimpan sebagai jaringan-jaringan proposisi-proposisi. Sikap merupakan pembawaan yang dapat mempengaruhi prilaku seseorang terhadap kejadian. Keterampilan motorik tidak hanya mencangkup kegiatan fisik, tetapi juga kegiatan motorik yang digabung dengan keterampilan intelektual.

Dengan adanya teori belajar Bruner dan Gagne diharapkan dapat memperbaiki rendahnya kelancaran posedural matematis siswa pada materi persamaan eksponen kelas X SMA Negeri 2 Singkawang, sehingga siswa memeliki prestasi belajar dan hasil belajar matematika yang baik

\section{KESIMPULAN DAN SARAN}

\section{KESIMPULAN}

Berdasarkan hasil pengolahan data penelitian yang dilakukan dapat disimpulkan bahwa; (a)
Persentase kelancaran prosedural matematis siswa kelompok atas yaitu 64\% dengan kategori rendah, persentase kelancaran prosedural matematis pada indikator fleksibel yaitu $74 \%$ dengan kategori sedang berada pada tingkat kedua, persentase kelancaran prosedural matematis pada indikator efisien yaitu $78 \%$ dengan kategori sedang berada pada tingkat pertama, dan persentase kelancaran prosedural matematis pada indikator efektif yaitu $41 \%$ dengan kategori sangat rendah berada pada tingkat ketiga; (b) Persentase kelancaran prosedural matematis siswa kelompok tengah yaitu 53\% dengan kategori sangat rendah, persentase kelancaran prosedural matematis pada indikator fleksibel yaitu $90 \%$ dengan ketegori sangat tinggi berada pada tingkat pertama, persentase kelancaran prosedural matematis pada indikator efisien yaitu $36 \%$ dengan kategori sangat rendah berada pada tingkat kedua, dan persentase kelancaran prosedural matematis pada indikator efektif yaitu 33\% dengan kategori sangat rendah berada pada tingkat ketiga; (c) Persentase kelancaran prosedural matematis siswa kelompok bawah yaitu 34\% dengan kategori sangat rendah, persentase kelancaran prosedural matematis pada indikator fleksibel yaitu $48 \%$ dengan kategori sangat rendah berada pada tingkat pertama, persentase kelancaran prosedural matematis pada indikator efisien yaitu 33\% dengan kategori sangat rendah berada pada tingkat kedua, dan persentase kelancaran prosedural matematis pada indikator efektif yaitu $22 \%$ dengan kategori sangat rendah berada pada tingkat ketiga.

SARAN

Dalam menyelesaikan soal tes kelancaran prosedural matematis pada materi persamaan eksponen, sebaiknya siswa teliti dan memahami kalimat perintah soal, teliti dalam menghitung dan menguasai prosedur pada materi persamaan eksponen serta materi prasyarat seperti materi bentuk pangkatan dan akar. Guru diharapkan dapat menekankan kelancaran prosedural matematis siswa dalam menyelesaikan masalah. Selain itu diharapkan guru ketelitian siswa dalam melaksanakan perhitungan dan memahami soal yang diberikan, sehingga siswa dapat menyelesaikan soal dengan benar dan hasil yang maksimal. Untuk penelitian lanjutan agar mecari 
pendekatan atau model pembelajaran yang tepat dalam meningkatkan keterampilan kelancaran prosedural matematis siswa pada materi persamaan eksponen. Sehingga siswa mempunyai keterampilan kelancaran prosedural matematis yang baik dalam menyelesaikan masalah pada materi persamaan eksponen.

\section{UCAPAN TERIMAKASIH}

Penulis mengucapkan terima kasih kepada Drs. Andi Mursidi, M.Si selaku Ketua STKIP Singkawang, dosen pembimbing yaitu Citra Utami, M.Pd dan Nindy Citroresmi P, M.Pd yang telah membimbing, memberikan saran, masukan serta pengarahan penulis, sehingga penulis dapat menyelesaikan jurnal ini. Kemudian penulis juga mengucapkan terima kasih kepada STKIP Singkawang yang telah mendukung dan mamfasilitasi penulis dalam menyelesaikan jurnal ini.

\section{DAFTAR PUSTAKA}

Aliyansah. (2013). Metode Penelitian Pendidikan. Singkawang: STIT SA Singkawang.

Aprianti, Rini. (2014). Kelancaran Prosedural Matematis Siswa dalam Materi Operasi Hitung Pecahan Aljabar Kelas VII SMP. Skripsi: Universitas Tanjungpura Pontianak.

Arikunto, Suharsimi. (2010). Prosedur Penelitian Suatu Pendekatan Praktik. Jakarta: PT Rineka Cipta.

Dahar, Ratna Wilis. (2006). Teori-Teori Belajar dan Pembelajaran. Bandung: Erlangga.

Hamzah, Ali \& Muhlisrarini. (2014). Evaluasi Pembelajaran Matematika. Jakarta: PT Raja Grafinda Persada.

Kilpatrick, Jeremy. Swafford, Jane. \& Findell, Bradford. (2001). Adding It Up: Helping Children Learn Mathematics. England: National Academy of Sciences.

Nawawi, Hadari. (2015). Metode Penelitian Bidang Sosial. Yogyakarta: Gadjah Mada University Press.

Rosmaiyadi. (2017). ANALISIS KEMAMPUAN BERPIKIR KRITIS MATEMATIS SISWA DALAM LEARNING CYCLE 7E BERDASARKAN GAYA BELAJAR. Jurnal Aksioma, 6(1), 12-19.

Sari, A. N., Wahyuni, R., \& Rosmaiyadi. (2016). Penerapan Pendekatan Open-Ended untuk Meningkatkan Kemampuan Berpikir Kritis Siswa Pada Materi Aljabar Kelas VIII SMP Negeri 10 Pemangkat. Jurnal Pendidikan Matematika Indonesia, 1(1), 20-24.

Sembiring, Suwah dkk. (2012). Matematika Kelas X. Bandung: Yrama Widya.

Silalahi, Ulber. (2009). Metode Penelitian Sosial. Bandung: Refika Aditama Siregar, Syofian. (2014). Statistik Parametrik. Jakarta: PT Bumi Aksara

Stott, Debbie. (2013). Learning \& Teaching Mathematics. Afrika Selatan: Rhodes University.

Sugiyono. (2010). Metode Penelitian Kualitatif kuantitatif dan $R \& D$ Bandung: Alfabeta.

Sullivan, Peter. (2011). Teaching Mathematics: Using Research-Informed Strategies. Australia: Australian Council for Educational Research. 